\title{
КЊИЖЕВНОСТ И ФОТОГРАФИЈЕ РОЏЕРА ФЕНТОНА У КОНТЕКСТУ ВИКТОРИЈАНИЗМА
}

Апстракт: У овом раду доводимо у везу викторијанску књижевност, пре свега, Алису у земли чуда Луиса Керола и песму о рањеном јелену Емили Дикинсон, с Фентоновим фотографијама из Кримског рата и јелена. Притом се снажна симболика јелена и његова трансформација у викторијанској књижевности доводи у везу с приказом рањеног војника на Фентоновој фотографији. Поређењем једне сцене на ратним фотографијама, као и фотографијама јелена и рањеног војника, с оним описаним у викторијанској књижевности, покушавамо дубље да проникнемо у саму фотографију помоћу богатства књижевног језика. Исто тако проналазимо и оно што нам фотографија и њен визуелни језик веома јасно предочава, а што је књижевности промакло или јој је потребно превише речи да би то постигла. С обзиром на крајње сложен однос између књижевности и фотографије, у контексту тзв. фотокњижевности, покушали смо да га осветлимо, и то на веома малом узорку појединих сегмената неколико књижевних дела и Фентонових фотографија.

Кључне речи: викторијанска књижевност, Алиса у земљи чуда, песма о рањеном јелену, фотографије Роџера Фентона, фотокњижевност, јелен-човек трансформација, рањени војник, мртав војник.

\section{Кримски рат и фотографије Роџера Фентона}

Прве ратне фотографије настале су у Америчко-мексичком рату, и оду тих неколико дагеротипија најпознатија је она непознатог аутора (највероватније неког мексичког дагеротиписте) из 1846. године која приказује улазак америчког генерала Џона Вула (John Wool) с коњицом у Салтиљо током зиме. Међутим, тек су у Кримском рату настале систематично повезане и уоквирене серије фотографија познатих фотографа, међу којима се истиче Роџер Фентон (Roger Fenton). Он је заједно са својим помоћником Маркусом Спарлингом (Marcus Sparling) и возачем у фургону-лабораторији с коњском запрегом - преуређеним да буде и мрачна комора, кухиња и спаваоница стигао 8. марта 1855. године у Балаклаву. Његова фотографска опрема се састојала од пет фотоапарата, 700 стаклених плоча, свих неопходних хемикалија и прибора за мрачну комору, шатора, инструмената и конзервиране хране. На Криму су владали тешки услови, а поред прашине и мува, велика врућина током лета те године утицала је на то да се колодијумска емулзија осуши (спречавајући погодну експозицију) пре него што је слика забележена. ${ }^{1}$ За процес

1 Фентон је у вези с тим у једном извештају навео следећи пример: „Кад су врата вагона била затворена пре него што је плоча припремљена, зној се сливао низ моје лице 
с колодијумом или мокром плочом било је потребно до 20 секунди експозиције у већини ситуација, а то је спречавало Фентона да чак и покуша да фотографише војне акције. Он је тако морао да се задовољи фотографисањем портрета војника, као и бојног поља дуго након што се битка завршила (в. Davenport 1999: 147). ${ }^{2}$ Фентон, дакле, није могао због непостојања момент-снимака да забележи кључне тренутке током самих борби у Кримском рату, али су још неки разлози за његову прилично лиричну и бенигну представу суровог рата. Наиме, влада је њему и другим британским фотографима дала упутства у циљу делимичног прикривања тешких услова, болести, глади и погибија војника.

Ни на једној Фентоновој фотографији није приказан мртав енглески војник, а разлози за то леже у чињеници да је за Енглеску, као империјалну и колонијалну силу, било потпуно неприхватљиво извештавање о поразима њене војске. За разлику од Фентона који никада није фотографисао тела мртвих војника, Џејмс Робертсон (James) више је приказивао сцене смрти, разарања и насиља. Иако је издавачко предузеће Thomas Agnew \& Sons објавило и Фентонове и Робертсонове фотографије с Крима 1856. године, чини се да Егњу није ограничио Џејмса да прави само фотографије које је фаворизовала влада, можда и због његових других извора прихода. Треба напоменути да је Робертсон већ у раној фази Кримског рата 1854. направио фотографије о којима се мало зна - као и још неки фотографи и сликари, попут Феличеа Беата (Felice Beato), Жана Шарла Ланглое (Jean-Charles Langlois), Карла Батиста фон Сатмарија (Baptist von Szatmari) - да би се потом поново вратио 1855. године на ратиште и фотографисао завршне фазе Кримског рата (в. Hannavy 2008: 1468). ${ }^{3}$

Фентон није приказивао чак ни рањене војнике, а изузетак у том погледу је фотографија Ранени зуав (1855). ${ }^{4}$ У доњем делу ове фотографије, лежи рањени зуав (назив за француског војника у Африци) са завојем преко главе коју му десно придржава други војник, док с леве стране болничарка у клечећем положају левом руком пружа чашу пића сипаног из флаше коју држи у десној руци. Све делује

и падао као сузе... Вода за развијање је тако врућа да тешко могу да у њу ставим руке“ (Newhall 1982: 85).

2 Стога је једино могао да фотографише умирујуће пејзаже изван терена масовног покоља (Balakian 2015: 92).

3 Беато је исто тако фотографисао лешеве (в. Davenport 1999: 147).

4 Године 1855. урадио је и серију фотографија аутопортрета где се нашао у улози зуава, у одговарајућој униформи и с пушком у руци. Гордон Болдвин (Gordon Baldwin) сматра да је „Фентонова намера била да представи себе у дугој традицији уметникових аутопортрета у егзотичној одећи, што датира још од Рембранта (Rembrandt) и укључује Роџерове раскалашне описе себе у униформи зуава“" (Baldwin 1996: 55). И српски фотограф Драгиша Стојадиновић позира с пушком и у поречком белом оделу на фотографији из 1907. године. 
као да је у извесној мери инсценирано, болничарка с пићем, војник у чучећем ставу, такође и неприродан положај ногу рањеног војника где је десна чизма прекрштена преко леве у донекле опуштеном ставу, а целокупан утисак нарочито појачава пушка која као да је намерно постављена тик испред рањеникове леве руке и паралелно с његовим телом. ${ }^{5}$ Роберт Хирш (Robert Hirsch) истиче како тај однос између болничарке и рањеног војника имплицира да су ужасни болнички услови о којима је извештавано у штампи били побољшани: „Ако се верује у оно што се види, онда су Фентонове слике показивале да бити рањен није забрињавајуће. Али ако би се то десило, херојска болничарка би видала ваше ране и водила бригу о вама“ (Hirsch 2017: 103). ${ }^{6}$

Роџер Фентон се пре Кримског рата није бавио пејзажном фотографијом, углавном је снимао портрете краљевске породице и историјску архитектуру у Русији, као што је грађење моста преко Дњепра код Кијева. Грејем Кларк (Graham Clarke) истиче како је Фентон у свом приступу пејзажу рефлектовао веома специфичан културни вокабулар заснован на књижевности и сликарству, и да је он често фотографисао званичне туристичке области описане у књижевности (Clarke 1990: 56). Међутим, његове ратне, као и предратне фотографије не пружају ни приближно онолико информација колико нам то омогућује књижевност. Додатни проблем код Фентонових

5 Александар Гарднер (Alexander Gardner) је након Америчког грађанског рата давао детаљне информације о својим фотографијама, па је тако у вези с фотографијом Дом стирелиа йобуюеника, Гетиисбурі (1863) напоменуо да је два пута посетио сцену у Гетисбургу. Након прве посете и фотографисања 4. јула, дан после завршетка битке (1-3. јула), детаљно је описао окружење, положај војника Конфедерације стешњеног између два огромна камена и да је погођен у главу гелером гранате која је експлодирала изнад њега. Током друге посете, 19. новембра, од војника је остао скелет који је неоштећен лежао унутар иструлеле униформе, а мускета, зарђала од многих олуја, још увек је била наслоњена на стену (в. Conn 1989: 220). Међутим, Гарднер је леш померио до каменог зида и подбочио његову главу ранцем како би била окренута ка фотоапарату, а пушка наслоњена на камену стену била је део фотографовог инвентара за фотографисање који је увек носио са собом. И кад је реч о чувеној фотографији Пали војник (1936), једног од најпознатијих ратних фотографа Роберта Капе (Robert Capa), постоје мишљења да војникова шака леве руке не може да буде у том положају какав је на фотографији, и да човек који је погођен метком и пада не стеже шаку на тако неприродан начин. Ово би могло да укаже на то како је прави припадник народне шпанске војске одглумио, односно позирао Капи, а да је недуго након тога и стварно погинуо у некој од борби с Франковим снагама.

6 Прва асоцијација, дубоко укорењена у српском етосу, када посматрамо ову Фентонову фотографију, може бити на слику Уроша Предића Косовка gевојка (1919). На овој слици Косовка девојка (модел Београђанка Лепосава Станковић), слично Фентоновој болничарки, поји рањеног српског јунака Орловић Павла водом из златног путира. Ипак, овде су свуда по бојишту распрострти лешеви војника и коња, од којих се у првом плану истичу она два Турчина, а позадина је, иако приказује натмурено небо, јасна за разлику од Фентонове са шаторима која је због неоштрог фокуса замућена. Такође, мач на Предићевој слици, који је сломљен на врху и окрвављен, положен је међу Павлове ноге у природном положају за разлику од пушке на Фентоновој фотографији Ранени зуав. 
ратних фотографија јесте тај што оне чак не замрзавају ни врхунац акције него идеализовани тренутак, инсценацију привида реалне слике. На његовим фотографијама може се запазити у одређеној мери романтички и идеализовани приказ официра, генерала на коњима с мноштвом краљевских обележја и паша с пратњом - који је произашао из упутстава британске владе да се из фотографија у великој мери искључе бројне жртве, болести и несташица намирница и гладовање због којег су војници пљачкали цивиле, као и да се инсценираним фотографијама ублаже и релативизују извештаји у британској штампи такве врсте.

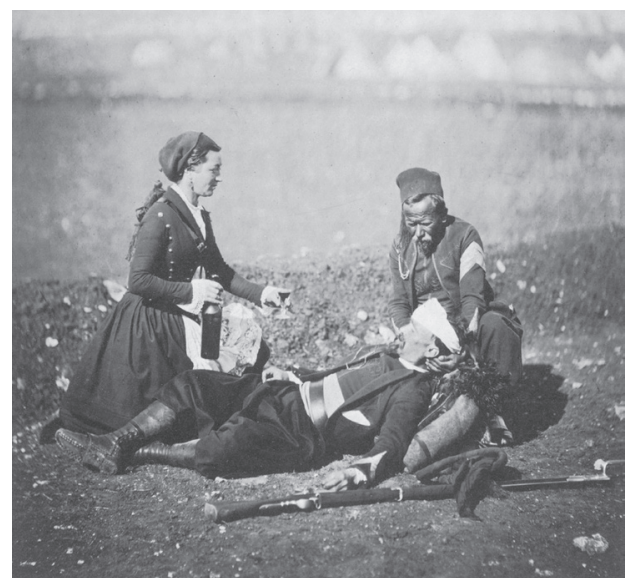

Фотогр. 1: Роџер Фентон, Ранени Зуав, 1855.

Фентон је био један од првих ратних фотографа. Рођен је у Кримбл Холу, једној од најлепших енглеских области, неколико километара северно од Манчестера у Ланкаширу, коју ипак није заобишла индустријска револуција. Од 1836. до 1840. године учио је латински, грчки, енглески, математику, књижевност и логику на Универзитетском колеџу у Лондону. Иако је 1839. почео да се припрема за правничку каријеру, он је то оставио по страни како би се бавио сликарством у Паризу и Лондону. У лето 1852. године Фентон није само открио своју нову професију - фотографију и етаблирао се као водећа фигура у својој растућој заједници него је такође пробудио страствену, амбициозну посвећеност која му је била непозната у ранијем животу (в. Baldwin et al. 2006). Он је и један од првих фотографа који је продавао портфолије својих радова као уметност. Притом је продавао ограничена издања портфолија оригиналних позитива и био је један од првих људи који је то радио. Луис Керол (Чарлс Латвиџ Доџсон - Charles Lutwidge Dodgson) и Џулија Маргарет Камерон (Julia Cameron) имали су мању улогу у конструисању фотографије као уметничке професије. ${ }^{8}$ Тако су они сматрали себе

7 Изузимање ових утицаја који су долазили од британске владе омогућује нам да се усредсредимо, пре свега, на стил овог енглеског фотографа и адвоката који је раних 1840-их година заједно са Гиставом Грејом (Gustave Le Gray), Шарлом Негром (Charles Nègre) и Анријем Ле Секом (Henri Le Secq) учио у атељеу Пола Делароша (Paul Delaroche).

8 Ипак, Луис Керол, један од веома цењених писаца тог периода, уједно је био и ентузијастичан фотограф; игром случаја, за фотографију је почео да се интересује управо током Кримског рата и за живота је направио око 3.000 фотографија (подухват који je, за период употребе влажне колодијумске емулзије у изради фотографија, захтевао 
аматерима и били мање заинтересовани од, рецимо, Хенрија Пича Робинсона (Henry Peach Robinson), за стварање високо углађених, беспрекорно конструисаних слика (Garcia 2010: 7). ${ }^{9}$ Промена у клубовима и друштвима касних 1850-их и 1860-их година паралелно се кретала од појединачне, личне и експерименталне употребе фотографије аматера ка њеном коришћењу као забаве за много ширу публику. Током позних 1950-их година регионална и локална фотографска друштва су се умножавала, окупљала људе, олакшавала размену информација и организовала изложбе (Seiberling and Bloore 1986: 92).

Много Фентонових радова је урађено у документарној форми. Међутим, кад је реч о Кримском рату и његовим фотографијама, ту је потребно направити дистинкцију у односу на жанр документарне фотографије, односно узети у обзир чињеницу да су неки савремени фотографи приказивали ситуације знатно објективније него што је то чинио Фентон (в. Bull 2020: 509). Међу њима се истичу Алан Секула (Allan Sekula) код кога је видљиво упаривање искустава текста и документарне фотографије, затим Донован Вајли (Donovan Wylie) који комбинује дневнике свог деде и проширене породичне албуме са сопственим фотографијама, Роџер Бален (Roger Ballen), који је фотографисао куће и људе у малом јужноафричком граду, Дирдре Окалахан (Deirdre O’Callaghan), која се бави хуманистичком документарном фотографијом и развија емпатију према заборављеној генерацији радника миграната и др. Документарно се појавило као популарна пракса у различитим медијима тек након Првог светског рата, и развијала се током 20. века. Ово рођење документарног као популарне форме је историјски повезано са све већим утицајем штампе, нарочито 1920-их и 1930-их година, и чак током Другог светског рата (в. Bate 2009: 45). Након што је видела много слика из Првог светског рата, јавност је почела да сматра фотографију за нешто нормално, а процес ротогравуре је чинио сликовни одељак новина практичнијим (то је омогућило рађање многобројних илустрованих часописа). Управо су ратни фотографи на штампаним страницама добили шансу да постану први значајни талас вести, спортова и документарних фотографа (в. Rose et al. 2007: 774).

невероватну количину времена и сведочио о Кероловој преданости том позиву). Он не само што је фотографију и књижевност видео као једнако битне сфере свог живота већ је и писао о фотографији (“А Photographer’s Day Out”, "Hiawatha Photographing”, "Photography Extraordinary" и "The Legend of Scotland").

9 Џулија Маргарет Камерон била је тетка мајке Вирџиније Вулф (Virginia Woolf), Џулије Стивен (Julia Stephen). Стога и не чуди да се и Вулфова бавила аматерском фотографијом, иако је у својим писмима осуђивала професионалну фотографију. Вирџинија је још од своје петнаесте године била заокупљена фотографијама, писала о фотографији у својим дневницима, писмима и есејима, и користила је описно фотографске термине у фикцији. Фотографија је за Вулфову представљала „само око“, али оно које joj је омогућило да види јасније. Она је експериментисала и усавршавала технику тока свести, а њени породични албуми компоновани су у визуелним обрасцима пре него хронолошки (в. Humm 2009: 42, 44). 


\section{Невиност и смрт у Алиси у Земљи иуда и на Фентоновим фотографијама}

У роману Алиса у Земљи чуда (Alice in Wonderland, 1865) Луиса Керола акценат је стављен на невиност и сусретање са светом одраслих главне јунакиње, али и смрт која је наговештена само у одређеним ситуацијама. ${ }^{10}$ Ни у једном тренутку она се не манифестује посредством умирања неког од ликова јер је они избегавају неочекивано глатко и ослобођени тешке и дуготрајне атмосфере страха која би иначе требало да је сасвим уобичајена за такав један страшан тренутак. ${ }^{11}$ Тери Отен (Terry Otten) истиче како се у Кероловом роману претње, насиље и окрутност увек неутрализују и да, ако се ликови боре, нико не губи: „Алузије на смрт нису прави узроци ни за узбуну нити за очај. Смрт се појављује комично на крају Мишеве приче, на пример, а осим тамо где је Алиса забринута границе смртности изгледају непостојеће или ирелевантне“ (Otten 1982: 152). И на Фентоновим фотографијама изостаје смрт, иако се на лицима војника делимично назире да ће она ипак у немалом броју случајева касније и наступити. Такође, и њено присуство је снажније изражено него у Кероловом роману јер су у питању реалне, сурове ратне прилике, за разлику од Алисиног чудноватог света у који је утонула у сну.

На Фентоновим фотографијама се невиност која је само привидна због положаја војника који попут модела позирају супротставља смрти која ће ипак изван ових фотографија срушити ту представу. У роману се смрт макар помиње, она није искључена из саме структуре као што је то случај код Фентона, али приповедање о њој у шаљивом и безазленом маниру не ствара тако наглашен контраст у односу на Алисину младост и невиност. Алиса може да се скупи да буде висока

10 Стварна смрт провејава у роману једино кроз Алисино помињање како је њена мачка Дина појела мишеве и птице, на шта су уплашене Сврака и Канаринка одлучиле да напусте изборну трку. О смрти, међутим, можда најбоље сведочи песмица која се односи на расправу сина и оца, кроз сукоб између младости и старости, што опет упућује на Алисино нагло одрастање и сазревање у новом свету.

11 Тако је Алиса свесна да само ако на бочици пише „отров“ да је неће бити више, па тако испија напитак из боце на којој крупним штампаним словима пише „попиј ме“; затим долази у опасност да се удави у језеру насталом од њених суза, а алузија на смрт се прави њеном реченицом на француском упућеном мишу који плива у истом језеру: „Ou est ma chatte?“ (Где је моја мачка); исти Миш прича Алиси и другим животињама како је у прошлости пас Рундов планирао да не буде шкрт и осуди га на смрт након што га је затекао у кући; Бели Зец је уплашен да ће Војвоткиња наредити да га погубе ако не нађе лепезу и рукавице од јареће коже; Војвоткиња изговара да се Алиси одруби глава секиром, али је џелат, односно Куварица, била сувише заузета спремањем супе; и Краљица је наредила да се Шеширџији одруби глава јер је хтео да им силом убије време картама баштованима јер су засадили белу уместо црвене руже (спасла их је Алиса сакривши их у саксију), а Алиси јер јој је оповргавала при чему је Краљ рекао да је она ипак само дете, али је у тим случајевима остало само на томе јер их је Краљица на крају све помиловала; Алисин страх да ће Војвоткињина беба која се касније претворила у прасе бити убијена; јастог и Лажна Корњача који се спасавају од морских паса и да не буду скувани итд. (в. Керол 2006). 
десет инча или порасте да буде виша од дрвећа, и то је искривљење стварности простора који ми заузимамо у односу на друге предмете (в. Weiner and Kurpius 1995: 4). Фентон је у својим фотографијама из Кримског рата склањао и премештао лобање, топовску ђулад и друго оружје, стене, и то његово аранжирање представља неку врсту измишљотине која у Алиси у Земљи чуда поприма још шире размере. Како се Алиса повећава и смањује након што попије напитак или нешто поједе, рецимо парче велике печурке, тако и простор у коме се она налази постаје мањи или већи. И код Фентона се догађа прелаз, односно превазилажење простора слично оном Алисином кад постоји опасност да због непрестаног увећавања остане заглављена у неком простору (тада само одређени напитак може утицати на то да се она смањи), где је овај енглески фотограф током Кримском рата напустио затворени студио и заменио га знатно пространијим отвореним простором кримског бојишта.

У Кримском рату Фентон се наједном нашао у потпуно другачијим условима, где је на располагању имао тзв. велики фотографски студио на отвореном који је могао да „преуређује“ и „аранжира“ према свом нахођењу. А међуфазу је представљало његово фотографисање у спољашњем простору, између осталог и краљевске породице, па тако фотографија Кратьияа, йрини, Алберй и юихово осморо gеце у gворишйу Бакиніемске йалайе (1854) представља један од таквих примера. Исто тако, повећавање и смањивање на његовим ратним фотографијама огледа се у фотографисању у средњем или средње крупном плану војника који практично позирају, и у општем плану где их је Фентон у немалом броју случајева хватао а да они тога нису били свесни. Кад Керол описује Алисино енормно повећавање након што је попила напитак и услед тога заглављивање делова њеног тела у прозоре и димњак куће, као читаоци можемо да замислимо ту ситуацију. С друге стране, на Фентоновим фотографијама то не би био случај, чак и да је у питању затворен простор а не отворено пространство на Кримском бојишту јер фотографија не би могла да нам и кроз колажирање дочара ни приближно уверљиво као књижевност такво чудновато и нестварно стање у којем се нашао одређени актер, односно модел.

Од Алисиних суза, док је била девет стопа висока, у једном тренутку је настало и језеро које опет упућује у извесном смислу и на смрт јер се главна јунакиња уплашила да ће се у њему и удавити:

Боље би било да сам мање плакала! - рече Алиса пливајући тамо-амо и тражећи како да одатле изађе. - Скупо ћу сад то платити, удавићу се у сопственим сузама! То ће бити збиља чудно! Али ионако је све данас чудно! (Керол 2006: 16).

Џорџ Левин (George Levine) напомиње како живот почиње у планинама, из „заборављених извора“, а завршава се у мору, и да брзина 
воде и „висине“ страсти имају своје изворе у сасвим дословним висинама: „Озлоглашена истакнутост мора и утапања у викторијанској књижевности само наглашава неизбежност екстремног реализма који покушава да порекне. Вода је приступачније и стога природније 'место' у и око енглеског пејзажа“ (Levine 1983: 206). ${ }^{12}$ Интересантно је да је Фентон тек након Кримског рата правио пејзажне фотографије, међу којима је и фотографија Bogoūagu Лyі̄вuja, y Pont-y-Pair-y (1857). На овој помало идиличној фотографији камење одаје утисак спокоја и мира. ${ }^{13}$ Овакав утисак може се стећи и посматрањем серије Фентонових фотографија пристаништа с бродовима у Балаклави, које је урадио током Кримског рата. Уместо камења ту се појављују брда у позадини, а чак војници и коњи у првом плану не нарушавају тај спокој (иако све то представља увод за његово касније нарушавање ус-

Фотогр. 2: Роџер Фентон, Краљии, ирини, Алберит и нихово осморо gеце у gвориштиу Бакиніемске йалат̄е, 1854.

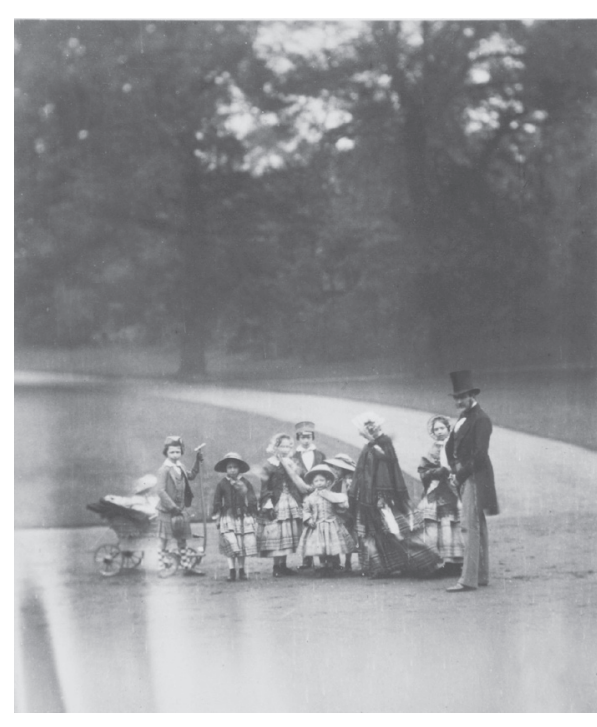

лед ратних дејстава), без обзира на то што су у акцији. За разлику од језера у Балаклави које је потпуно мирно, у Алисином језеру се одвија драма у којој учествује пре свега главна јунакиња која настоји да се не удави, али и миш и друге животиње које су напокон могле да буду спокојне када су доспеле до обале и ту се осушиле. Чак и да замислимо да се у језеру са Фентонових фотографија налази неки војник који се дави, или се, пак, одвија одређени сукоб, то би представљало тек један тренутак који не може попут књижевног знатно ширег описа да дочара сву напетост и борбу која се одвија, пре свега, унутар самих актера тог чина.

12 Британски империјализам била је популарна тема у деветнаестовековној књижевности, нарочито дечјој. Како је било сувише касно за убеђивање на други начин или поновно образовање одраслог становништва Енглеске, које је непоколебљиво прихватило империјализам, дечја фантазија била је савршен излаз за такве иконоборачке погледе. У империјалном контексту, Керолова прича може се читати као суптилно критиковање британског колонијализма (Bryan 2012: 22-23). Постоји неколико јасно дискурзивних слојева у писању Џејмса Ентонија Фруда (James Anthony Froude) о мору: океан је на једном нивоу херојски простор, такође и уточиште, али и национални терен или имовина у ексклузивном поседу Енглеза (Klein 2006: 113).

13 Фентонове пејзажне фотографије су добар показатељ викторијанских ставова према пејзажу (в. Clarke 1990: 57). На пејзажним фотографијама из периода после Кримског рата с водопадима и другим воденим површинама које углавном окружују стене и планине, Фентон је коначно нашао спокој након оног само привидног с ратних фотографија. 
Фотогр. 3: Роџер Фентон, Bogoūagu Лȳвиja, y Pont-y-Pair-y, 1857.

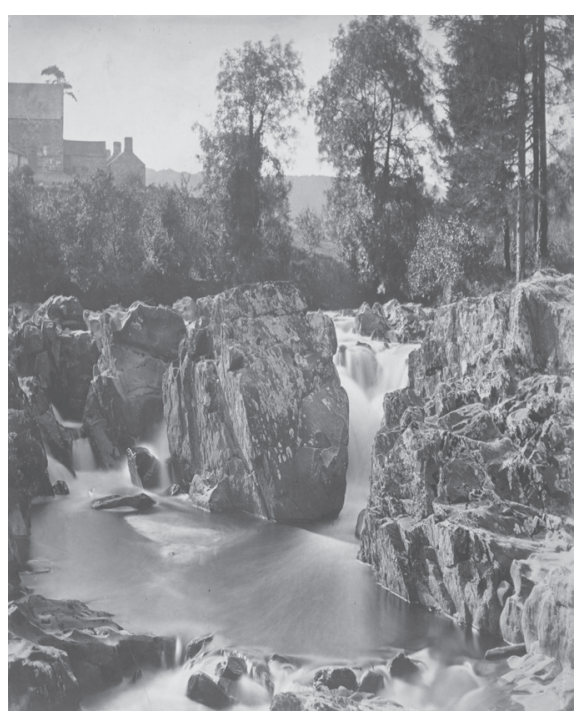

Кад је реч о војницима који као да позирају на Фентоновим фотографијама - иако се у непосредној близини одвијају, или he се недуго након тога одвијати борбе - може се направити паралела с децом која су Керолу послужила као фото-модели. Такође, можемо отићи још даље у тој анализи ослањајући се на још раније Фентонове изворе попут краљевске деце која су му позирала на предратним фотографијама. Луис Керол био је фасциниран (могуће и опседнут) веома младим девојчицама, нарочито Алисом Лидел (Alice Liddell), моделом за Алису y Земљи чуда, њеним сестрама и другим, и одлучио да их фотографише често у алегоријском костиму и пози (Warren et al. 2006: 707). ${ }^{14}$ Карол Мавор (Carol) се пита да ли је чудо што су Алис, Лорину и Едит (Edith) Лидел, као и Џорџа (George), Џека (Jack) и Питера Дејвиса (Peter Davis) немилосрдно сачували Керол и творац Петира Пана (Peter Pan) Џејмс Бари (James Barrie), не само у мастилу него и у емулзији, и закључује да њихове слике нису ни више ни мање него успомена на златну мрљу: „И фотографија и детињство прихватају свој облик и проницљивост за смрт. Ако не би било смрти, зашто би детињство чувало своју привлачност? Ако не би било смрти, зашто би наша жеља за фотографијом и да сачувамо последње тренутке били тако важни?“(Mavor 1995: 58). Овде се можемо надовезати и на post-mortem или меморијалну фотографију из викторијанског доба, када је због велике стопе смртности (нарочито беба и деце) била изражена потреба да се усниме покојни ближњи и на тај начин сачува успомена на њих. ${ }^{15}$ На post-mortem фотографијама живе особе, углавном покојникови најближи, имале су поред сентименталне и

14 Керол и Камерон имали су исту децу као моделе за своје фотографије, укључујући и Алис Лидел (в. Susina 2013).

15 Post-mortem фотографија је имала неколико намена: да утеши ожалошћене, да подели слику и детаље смрти вољене особе с онима који нису били тамо и да меморијализује покојне (в. Hannavay 2008: 1164). Она се први пут појавила за време викторијанског доба у Енглеској, а касније се проширила на остатак Европе и Сједињених Америчких Држава. Прављење приватних портрета мртвих била је друштвено прихваћена и широко распрострањена фотографска пракса у Европи и Северној Америци од 1840. па све до 1900-их година. У кратком временском периоду ова традиција привукла је растуће становништво, мада би требало истаћи да је проучавање те праксе било мало заступљено све до 1950-их година (в. Borgo, Licata et al. 2015: 104; Munforte 2015: 79). 
практичну сврху. Наиме, њихово присуство је омогућавало да мртви стоје у одређеном положају, без потпоре, сталка, жица и других справа које су биле неопходне уколико су они „позирали“ без живих. Стога у неким случајевима није могуће разликовати живе од покојних особа, нарочито кад је фотограф експериментисао са затвореним и отвореним очима.

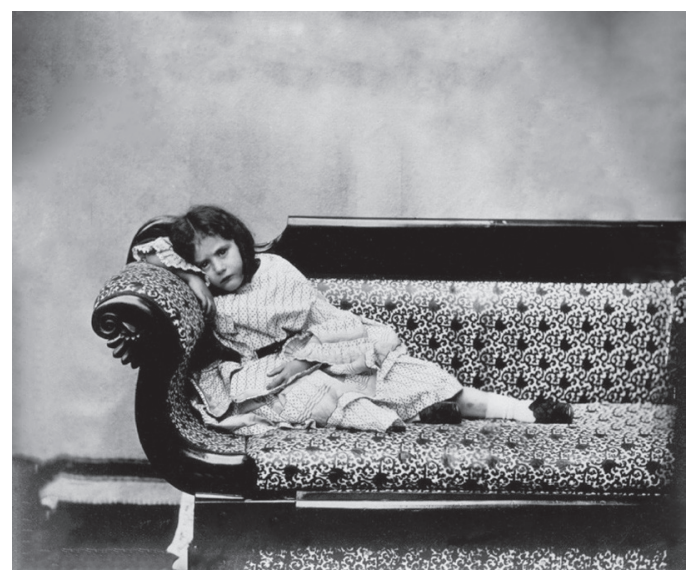

Фотогр. 4: Луис Керол, Еguй Лиgел у лежећем йоложају оивворених очију, 1860.

Посматрајући неке Керолове фотографије можемо доћи у такву врсту недоумице, поготово ако смо претходно истраживали и били под утиском post-mortem фотографија. То је нарочито случај с фотографијама где девојчице позирају на софи у лежећем положају, отворених и затворених очију као у сну, на пример, фотографије Александре Кичин (Alexandra Kitchin) из 1869. и 1872. године док спава на софи, Едит Лидел у лежећем положају отворених очију, али и фотографија из 1864. године на којој Мери Мекдоналд (Mary MacDonald) спава у кревету док с десне стране крај кревета седи отац с њеним братом у наручју. У том смислу ове фотографије могу имати и наративни ток својствен књижевности, првенствено ако се поставе на адекватан начин у одређену серију. За ову врсту истраживања могла би бити занимљива и фотографија, прецизније стереофотографија Р. Б. Витакера (Whittaker) из 1860-их година, на којој је иста покојна девојчица приказана у две различите позе у лежећем положају на софи, с леве стране са затвореним очима $\mathrm{y}$ чврстом сну а с десне

Фотогр. 5: Луис Керол, Мери Мекgоналg сйава у креветй док са десне сирране крај кревети а сеgи ойаи, са юеним братиом у наручју, 1864.

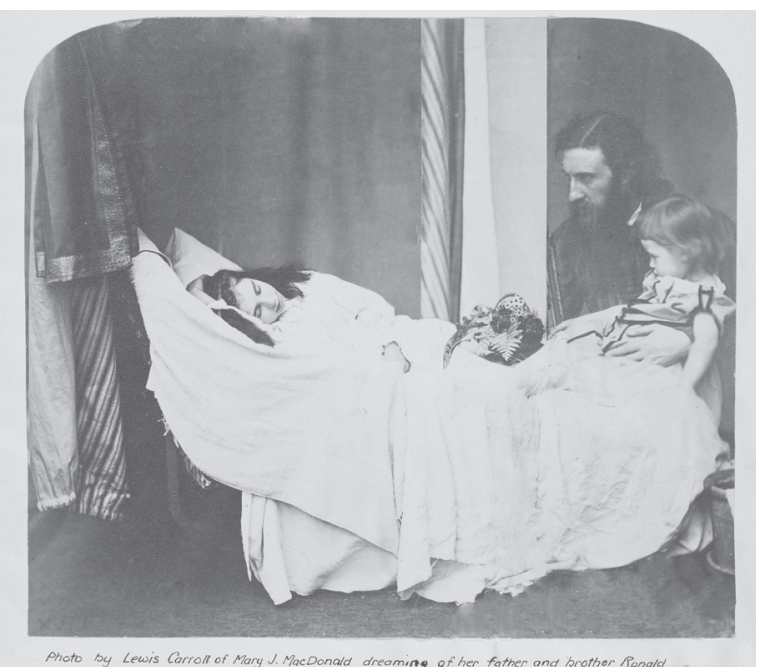


с отвореним очима као сасвим будна. Поменута стереофотографија не остварује просторну и физичку блискост с девојчицом него пре временско премештање које преокреће чињеницу смрти у фикцију живота. Ова промена је омогућила Витакеру да употреби наратив као стилско средство на слици како би створио фотографију пре и после која, читајући слику слева надесно, оставља утисак кретања подударног с временском димензијом: мртва девојчица се буди из вечног сна (в. Munforte 2015: 83-84).

\section{Јелен-човек: трансформација и појам одсуства у викторијанској књижевности и фотографији}

Империјалне претензије викторијанске Енглеске могу се запазити и у исказивању њене надмоћи на британском острву. Тако је краљица Викторија прихватила и пропагирала викторијанске стереотипе о Шкотима као примерима примитивне али племените мушкости и шкотским планинским крајевима као дивљим и забаченим, иако унутар богате цивилизоване Енглеске. У тако конструисаном прихватању и спектакуларизацији Шкотске, Викторија је јавно приказала енглеску контролу над дивљом мушком Шкотском (Martin 2009: 40). ${ }^{16}$ С друге стране, у шкотским планинским крајевима и острвима јелен се повезује с натприродним бићима, увек женским, и постоји много прича о јелен-човек трансформацијама (Miller 2014: 127). Чак и мртав, јелен је остао моћан симбол енглеског пораза и уједињења Шкотске (Martin 2009: 77). Овде видимо да су супротстављени симболика јелена у Шкотској и енглески, односно викторијански стереотипи о Шкотима, у смислу да се првом женском, супротставља са стране наметнути мушки принцип. Међутим, требало би узети у обзир чињеницу да су се касније околности промениле, па су се тако на Криму шкотски пукови борили заједно са Енглезима. Из тог разлога се двоструко значење симбола јелена може тумачити и у овом контексту, где се жртва касније идентификује с агресором, а мртав јелен кроз јелен-човек трансформацију постаје искључиво симбол пораза.

Јелен представља идеализовану људску форму - прву именовану могућност жељеног створења. Емили Дикинсон (Emily Dickinson) у својим песмама саосећа с уловљеним створењем препознајући његов статус као објекта жеље, али упркос томе истиче крај лова, неизбеж-

16 Викторијански сексуални дискурс је посебно идеализовао буржујско мушко тело, које се одликује здрављем и дуговечношћу, издржљивошћу и продуктивношћу, те пореклом и расом; буржујско мушко тело потом је употребљено за означавање инфериорних тела жена, нижих класа, незападњака и старих. Мишел Фуко (Michel Foucault) истиче како је од једноличних ноћи викторијанског грађанства сексуалност брижљиво затворена и увучена у стан: „Тај Енглез без идентитета, могао би, боље од своје владарке, да послужи као средишња личност историје модерне сексуалности која се већ ствара, великим делом уз хришћанску пасторалу“ (Fuko 1982: 9, 25). 
но рањавање јелена које испуњава своју улогу као игре (Pielak 2014: 233). ${ }^{17}$ Она у првој строфи песме о рањеном јелену описује последње тренутке једног јелена, од рањавања па све до његове смрти. Притом само последњи четврти стих има строго наративну функцију, док се остали не морају односити искључиво на датог јелена:

Рағени Јелен / скаче највише / Ловчево сам причање чула / То је само Екстаза смриии / Потом / Честа је утихнула! (Dikinson 1988: 47). ${ }^{18}$

Али без обзира на њихово универзално значење, ова прва три стиха не ремете наративну структуру, односно линију догађаја. Као и многи други јелени, и овај је најпре рањен и тада скаче највише, по причи ловца; тај тренутак је екстаза смрти, односно увод у коначну смрт јелена која је предочена његовим одсуством у последњем стиху.

Можда најпознатија Фентонова фотографија из Кримског рата јесте Долина сенке смртии (1855), практично једина без војника у главној улози којима је речено где и како да се поставе док позирају испред фотоапарата. Међутим, Фентон је чак и ову фотографију инсценирао јер је у првој верзији топовску ђулад укопао с леве стране од пута, а у другој, оној познатијој, разбацао их је насред пута. Иако је и у овој фотографији на неки начин прикрио пораз британске коњичке бригаде и погибију великог броја њених војника од стране руске артиљерије у бици код Балаклаве 25. октобра 1854. године, Фентон је на њој успео да пружи можда највернији приказ рата. ${ }^{19}$ Опустошена долина, вијугави пут који води у недоглед, раштркана топовска ђулад која, иако аранжирана, постају неми и мртви сведоци уништења замењујући тела мртвих војника, све ово гради снажну симболику која је само наговештена. Сузан Зонтаг (Susan Sontag) сматра како је „ова меморијална фотографија портрет одсуства, смрти без смрти“" (Sontag 2003: 40). Ово одсуство може се наслутити и у песми Дикинсонове и на Фентоновој фотографији јер ми не добијамо опис

17 Такође, њен јелен се може упоредити са саосећајним, угњетеним животињама Деборе Дененхолц Mорс (Deborah Denenholz Morse), које она поистовећује с империјално експлоатисаним, угроженим субјектима (Morse 2007: 181). На почетку викторијанског доба многи Американци су имали јаке предачке везе с Британијом (в. Adams, Pendergast et al. 2004). Дикинсонова је, међу осталим песницима и писцима у Америци тог доба, пример ширења викторијанског утицаја ван граница Европе, у земљи у великој експанзији која је раније једним делом била енглеска колонија.

18 На слици Фриде Кало (Kahlo) Рағени јелен (1946) позната мексичка сликарка је представила себе у метаморфозираном облику јелена. Ово створење, с телом јелена и главом Фриде (попут митолошких бића Минотаура, Кентаура и др.), смртно је рањено стрелама и крваво, што симболизује рањивост, бол и патњу, као последицу неуспешне операције кичме коју је уметница имала у Њујорку 1946. године.

19 У песми о овој бици „ууриш лаке коњице“ (The Charge of the Light Brigade, 1854), Алфред Лорд Тенисон (Tennyson) не прикрива дословно, као Фентон у поменутој фотографији, мртве енглеске војнике и њихову узалудну погибију: „Њихово није да питају зашто [...] њихово је да изврше или погину.“ А песникова констатација: „Неко је погрешио..." указује и на командну одговорност (в. Tennyson 1968). 


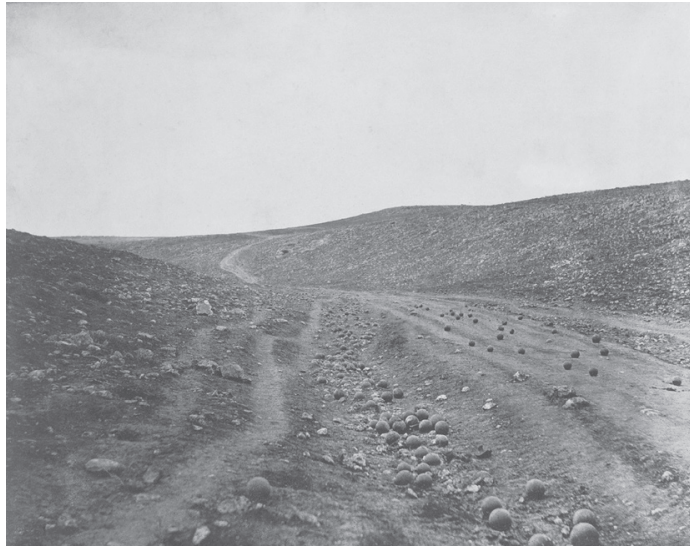

Фотогр. 6: Роџер Фентон,

Долина сенке смрити, 1855. нити видимо мртвог јелена или мртве војнике. Али зато смрт провејава у оба случаја, иако се није уобличила у сасвим јасној и видљивој форми; у песми је то смрт јелена који је нестао у утихнулој чести и чије се мртво тело не помиње, док је на фотографији реч о смрти војника представљених у обличју топовских ђулади. Дакле, већ саме речи ранени и

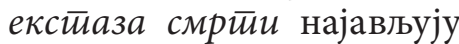
смрт јелена, а с уйихнула она постаје већ сасвим извесна. На фотографији се одвија трансформација, слична оној између јелена и човека, с тим што се уместо живих бића на крају појављују топовска ђулад као неживе ствари; иако немамо никакав опис као у књижевности, можемо на основу историјских података закључити како се на том месту прво одвијала борба између британске коњичке бригаде и руске артиљерије, и погибија енглеских војника, па су након тога на бојишту била разбацана мртва тела тих војника, да би се на крају они интервенцијом фотографа трансформисали у топовску ђулад.

Смрт је на Фентоновој фотографији присутна негде у даљини, далеко иза нашег видокруга, можемо је само на основу постојећих елемената у првом плану наслутити, и пратећи пут којем се крај не назире схватити да је њено обличје неухватљиво. И препарирани јелен на фотографији Џона Дилвина Луелина (John Dillwyn Llewelyn) Јелен у шуми (1852) није више мртав већ окамењен попут статуе, то је заправо фотографија мртвог јелена представљеног у форми укрућене препариране животиње. ${ }^{20}$ Иако и топовску ђулад можемо тумачити као окамењена тела мртвих војника, то ипак није фотографија истих мртвих војника јер се њихов облик не назире ни у каквој форми. Али њихово одсуство не спречава нас да, такође од-

20 На овој фотографији мртав јелен се захваљујући таксидермији трансформише из леша у препарирану животињу и на танкој је граници јер све време кокетира са скулптуром. Метју Брауер (Matthew Brower) напомиње да „ближи поглед на конјункцију главе и тела јелена открива да нешто није сасвим исправно, како је поза јелена у супротности с његовим окружењем, угао врата је погрешан, а укрућене предње ноге и четвртасте груди одају статус јелена као препариране животиње“ (Brower 2011: 9-10). Шума није природно окружење препарираног јелена, као што и амбијент изван самог бојишта у коме се налазе војници на Фентоновим фотографијама не одражава реално стање на терену; препарираном јелену је место у природњачком музеју, Фентонови војници као да позирају у студију који је толико далек рату, у свету који је потпуно изолован од оног који је оличење страдања и ужаса. 
сутну смрт, доведемо у везу управо с војницима и њиховом рањивошћу док су још као живи приказани на фотографијама а потом и њихово стварно уништење, а не оно посредством саме слике. Сузан Зонтаг напомиње како „фотографије исказују невиност, рањивост живота који иде ка сопственом уништењу и та спона између фотографије и смрти као дух прати све фотографије људи“ (Sontag 2009: 73). Фентонове ратне фотографије делују шаблонизовано, као да је аутор у њих по аутоматизму унео обрасце из својих предратних портретних и архитектонских фотографија. Занимљиво је то на који начин се он пре избегавања да фотографише мртве војнике на Криму, оболевања од колере у јуну 1855. године и повратка у Енглеску, у својим предратним фотографијама Мрйав јелен (1852) и Мрйав јелен на сииени на један другачији начин суочио са смрћу коју је у извесном смислу касније на ратишту избегавао. ${ }^{21}$ У прва два стиха следеће строфе: „Шикља стена ударена! / Па мач згажени који скаче!“", Дикинсонова уводи стену као симбол замрлог живота, али и трајности која наговештава нови, неовоземаљски и вечни живот. ${ }^{22}$ Дикинсонова посредством ова два, али и претходних стихова, уноси и елеменат динамизма, док је код Фентона присутна статичност, али само привидна јер атмосфера његове фотографије ствара утисак као да се у било ком тренутку може догодити метафоричка трансформација, сада у обрнутом смеру.

Сходно немогућности да у једној фотографији, за разлику од књижевности, видимо све што је претходило оном приказаном, или што ће тек уследити, и сама Долина сенке смрйи нам не пружа довољно информација. Међутим, познавање чињеница у вези с ранијим Фентоновим фотографијама, конкретно Мрйвим јеленом и мрйвим јеленом на сйени, може нам указати на оно што се у његовим каснијим ратним фотографијама претворило у јелен-човек, тачније јелен-војник трансформацију што, наравно, подразумева сагледавање серије фотографија, а не само једне. У серији фотографија с Крима ти војници гину, али се њихова погибија не види на фотографијама. Франсоа Сулаж (François Soulages) сматра да „фотографисати увек значи усмртити оно што је живо, чак и кад та смрт може да изнедри уметничко васкрсење“ (Sulaž 2008: 302), а у случају Фентонових војника прилика за то је постојала док су практично живи

21 Ми не знамо шта се тачно дешавало раније и непосредно пре смрти јелена, тачније, да ли су фотограф и ова животиња успоставили било какву релацију. Немачки филозоф Ернст Тугендхат пише о страху од смрти животиње: „Док у случају вегетативног страха од смрти нама блиске животиње, иако не реагују исто, реагују слично људима, не може се у случају овог другог типа страха од смрти претпоставити да друге животиње познају страх да ће ускоро умрети јер је за то потребан језик и свест о времену: мора се разумети реч 'ускоро“" (Tugendhat 2010: 13).

22 Међутим, већ из треће строфе: „Радост је Оклоп којим Патња / Опрезно је наоружана / Да не би неко крв видео / И узвикнуо: 'Гледај, рана!'“, можемо закључити да се Дикинсонова ослања на слику уловљеног јелена како би испричала причу о замраченој људској емоцији (в. Pielak 2014: 232). 
позирали изван бојишта. Код Дикинсонове добијамо информацију о јелену који је погођен и умире (али који и нестаје у чести), и он се трансформише у неживу стену из које притом шикља крв. Овде можемо уочити сличност између стене и Фентонових топовских ђулади (као и стене из раније фотографије мртвог јелена), али из ових других не шикља нити се појављује крв. Управо је то једна од главних карактеристика фотографије, да нам не пружи оно што бисмо можда очекивали да видимо већ да подстакне нашу имагинацију.

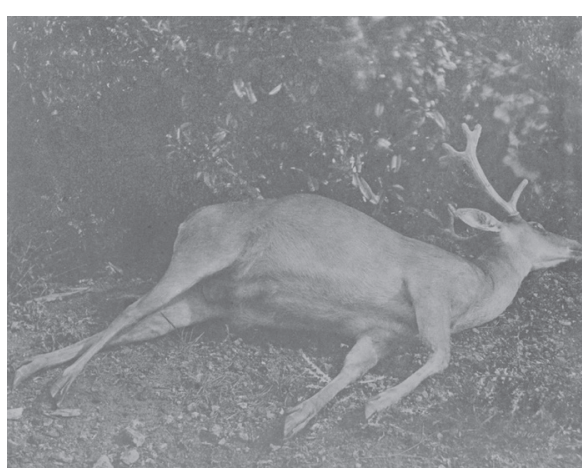

Фотогр. 7: Роџер Фентон, мрйав јелен, 1852.

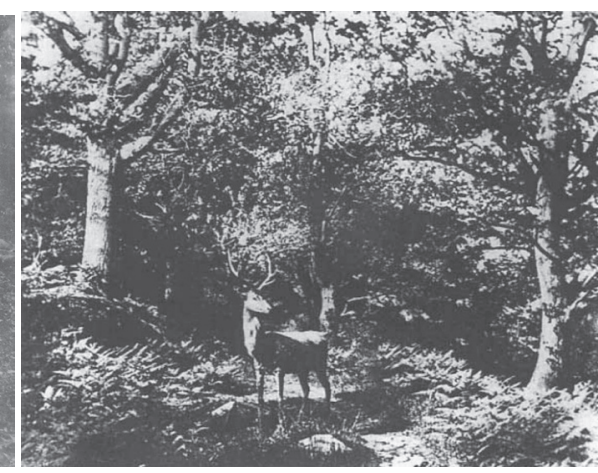

Фотогр. 8: Џон Дилвин Луелин, Јелен у иуми, 1852.

\section{Симболика и трансформација јелена на Фентоновим фотографијама и у књижевности}

У књижевности се изражава одређено поштовање према јелену, он се сматра за једно од најнежнијих, најлепших и најневинијих створења у животињском царству. Такође, присуство јелена симболизује мирно и хармонично пребивалиште (Camuri, Fossati et al. 1993: 30). Невиност није јединствени концепт током викторијанског периода, а невино тело игра двозначну улогу у викторијанској књижевности (Davis 1993: 15, 24). Та двозначност може се уочити и у фотографском стилу Фентона, који је још на самом почетку наилазио на тешкоће приликом фотографисања краљице Викторије и краљевске деце јер није имао још довољно искуства с портретима, а и радио је у импровизованом студију који вероватно није било могуће преуредити. Нарочито је имао проблем с формалном природом самих tableaux vivants и приказивањем деце на њима јер су она била нестрпљива због дугих позирања и било им је неудобно у костимима. ${ }^{23}$ Исто тако, за разлику од одраслих у игри на салонским представљањима, дечји осећај

23 У викторијанско доба је за многе фотографија била ретка и скупа, а post-mortem фотографија је могла да буде једина фотографија или слика одређене особе. Најчешће post-mortem фотографије јесу оне које приказују децу и бебе, не само због велике стопе смртности него и због чињенице да је на почетку развоја фотографије субјект морао да буде миран десет и више минута. 
ослобађања од свакодневног викторијанског живота мора да је био минималан, ограничен зато што су позирала пред фотоапаратом. Ове слике су више креиране да забележе костиме и обележе прилику него да причају причу, и као такве не спадају у категорију жанровских фотографија (Baldwin 1996: 72). ${ }^{24}$ У евангелистичкој перцепцији детињства тело детета би требало да научи да пати тако да његова душа може бити очишћена, и ово је у супротности с популарнијим концептом детета у викторијанској књижевности као симбола невиности које треба заштитити (Sattaur 2011: 70). Питер Ковенеј (Peter Coveney), један од првих модерних проучавалаца детета у књижевности, сматра да је за викторијанце детињство било симбол медијације у периоду спиритуалних криза. ${ }^{25}$ По њему би кроз дете могла да се изрази уметникова свесност о људској невиности насупрот кумулативних притисака социјалног искуства (Coveney 1967). ${ }^{26}$

Док би прва Фентонова фотографија на којој мртав јелен лежи испред грмља могла да делује као реална, јелен на другој је у неприродном положају а стена на коју је он постављен додатно појачава утисак да је све инсценирано. ${ }^{27}$

Фотогр. 9: Роџер Фентон, Бриїаяни іенерал Ван Сйраубензе и обииири, 1855.

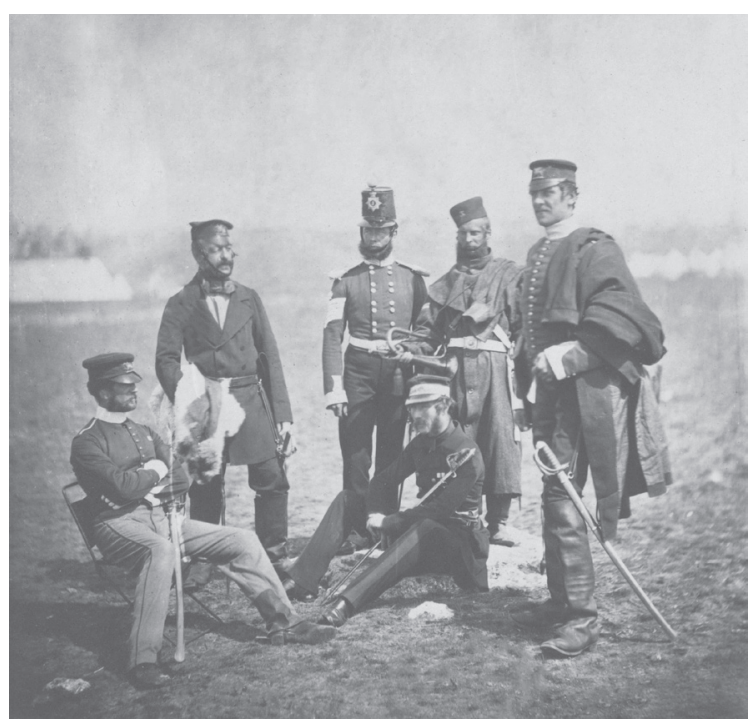

24 И ово фотографисање краљице Викторије и краљевске деце које је претходило Фентоновим ратним фотографијама утицало је у одређеној мери да и војсковође и војници изгледају као да спокојно, у мирнодопским условима и ослобођени ратних брига, позирају пред фотоапаратом.

25 Спиритуалисти су схватали спиритуалну фотографију као средство којим се пружају визуелни докази бесмртности и постојања живота после смрти (Baetens, Streitberger et al. 2010: 28).

26 Ковенеј такође напомиње како за енглеског романтичког песника и сликара Вилијама Блејка (William Blake) деца нису била предмет повременог интересовања, средство за пуку личну носталгију. За њега су она била симбол невиности, без којег, као религијски уметник, он није могао да ствара (Coveney 1967: 52). У Пролећу из Блејкових „Песама невиности и искуства“ (Songs of Innocence and of Experience, 1794), јагње, иако симбол меке невиности, такође је и жртва - јагње које ће бити одведено до кољача, чију ће меку вуну стргнути не дете него стрижач. Тако блиским повезивањем детета и јагњета, Блејк показује крхкост њихове невиности коју деле и неминовност њеног губитка (Flegel 2016: 46-47).

27 Услед потребе за дугачким експозицијама у првим годинама фотографије (1839- 
Ипак, у оба случаја се појављује леш јелена, а у другом примеру стена као симбол трајности метафорички продужава утихнули живот оличен у телу мртвог јелена. ${ }^{28}$ Ролан Барт (Roland Barthes) пише о Фотографији која је предмет његове интенције: „Имагинарно, она представља врло суптилан тренутак у којем, истину говорећи, нисам ни субјект ни објект већ пре субјект који осећа како постаје објект - дакле, тренутак кад преживљавам једно микроискуство смрти (стављања у заграде): заиста постајем сабласт" (Bart 2011: 19-20). ${ }^{29}$ У том смислу, и Фентонови војници као жива бића бивају усмрћени, али кроз њихове ликове додатно провејава и смрт коју фотограф из одређених разлога настоји да прикрије. Они на први поглед, с оружјем у рукама али и у мирном ставу модела, наликују Лисиповом Аресу Луgовисију - који иако у левој руци држи мач а уз десни бок му је прислоњен штит, не делује као ратник него као млад човек жељан мира, радости, живота и љубави - и попут њега, због чињенице да су фотографисани, као да су окамењени. ${ }^{30}$ А лешеви јелена на Фентоновим фотографијама, будући да нису живи, немају метафорички и експресивни потенцијал да се окамене, жива слика им то не допушта.

\section{Закључак}

У разматрању тзв. фотокњижевности тешко је утврдити прецизне полазне основе које би нам касније омогућиле дубљи увид у релације и међусобне утицаје књижевности, и фотографије. Као област и медиј, оне наилазе на бројне препреке које су резултат разлика и супротстављености у њиховим структурама. Проблем се јавља кад треба растумачити текстуално у визуелном, и обратно, односно пронаћи везу између онога што видимо, и што је, с друге стране,

1845), једино су фосили, мртве или препариране животиње могле бити фотографисане на металу и папиру (неки помоћу микроскопа), док се од средине 1840-их година припитомљене животиње у статичним позама појављују у дагеротипијама Бисона Фререa (Bisson Frères) и других. Од 1851. године приступ егзотичним живим животињама у новим јавним 'зоолошким вртовима' који се подудара с развојем бржих влажних колодијумских плоча, био је благодат за фотографе и подједнако научнике (Hannavy 2008: 40).

28 Ролан Барт сматра да у фотографији присуство ствари (у датом прошлом тренутку) никад није метафоричко: „Кад је реч о живим бићима, њихов живот није метафорички, осим када се фотографише леш; па чак ни тада: ако фотографија тада постане ужасна, то је зато што она сведочи о томе, ако могу тако да кажем, да је леш жив као леш - да је он жива слика једне мртве ствари“ (Bart 2011: 75).

29 Барт наставља: „Фотограф то добро зна; и он сам страхује (макар само из комерцијалних разлога) од те смрти у којој ће ме његов покрет балзамовати... Стиче се утисак да престрављени Фотограф мора дивовски да се бори како Фотографија не би постала смрт“" (Bart 2011: 20).

30 Сулаж мисли како „камени кипови оживљавају захваљујући фотографијама, да они имају нешто људско и изгледају као оживљени“ (Sulaž 2008: 302). 
описано. Најчешће је тај опис у књижевности знатно садржајнији и пружа много већи број информација од фотографије, која издваја само један замрзнути тренутак не откривајући оно што је у позадини. То подразумева да посматрач може само на основу те слике да формира естетски суд, или да евентуално продуби њено разумевање улажући додатне напоре у откривању скривених значењских подслојева. У овом случају је неопходно ставити у одређени контекст актере или објекте с фотографије, али и истражити све релевантне чињенице које могу указати на „предисторију“ те појединачне фотографије. На фотографији не можемо видети све оно што је претходило снимљеној сцени или одређеном сегменту, па из тог разлога добијамо испрекидан ток. Иако тај ток може бити потпунији укључивањем већег броја фотографија, ни одређена серија, или више серија, неће нам омогућити дубљи увид на начин како то чини књижевност. Иако и књижевно дело има своја скривена значења, оно пружа читаоцу много више материјала за тумачење, и то у једном мање-више непрекинутом току. Без обзира на то што су и Фентонове фотографије и књижевна дела Луиса Керола и Емили Дикинсон настали у викторијанско доба, сличности које се међу њима могу уочити нису нужно само резултат заједничких одлика викторијанизма. Оне су свакако произашле и из индивидуалних сензибилитета и стремљења ових стваралаца. Али управо дужа форма књижевног дела може представљати проблем у прављењу паралела с фотографијама. Ипак, у анализи поменутих књижевних дела и фотографија утврђивање заједничких карактеристика и симбола датог правца омогућило је да се у основи прилично лабаве везе међу њима колико толико учврсте.

\section{ЛИТЕРАТУРА}

Керол, Л. Алиса у Земль чуgа. Београд: Завод за уџбенике Београд, 2006. Adams, J. E., Pendergast, T. and Pendergast, S. (eds.). Encyclopedia of the Victorian Era. New York: Grolier Academic Reference, 2004.

Baetens, J., Streitberger, A. and Gelder, H. V. (eds.). Time and Photography. Leuven: Leuven University Press, 2010.

Balakian, P. „Photography, Visual Culture, and the Armenian Genocide“, In: Fehrenbach, $\mathrm{H}$ and Rodogno, D. (eds.). Humanitarian Photography: A History. Cambridge: Cambridge University Press, 2015. 89-115.

Baldwin, G. Roger Fenton: Pasha and Bayadère. Los Angeles: Getty Museum Studies on Art, 1996.

Balwin, G, Daniel, M. and Greenough, S. All the Mighty World: The Photographs of Roger Fenton, 1852-1860. New York: The Metropolitan Museum of Art, 2004. 
Bart, R. Svetla komora: beleška o fotografiji. Beograd: Kulturni centar Beograda, 2011.

Bate, D. Photography: The Key Concepts. Oxford, New York: Berg, 2009.

Borgo, M., Licata, M. and Iorio, S. „Post-mortem Photography: the Edge Where Life Meets Death?“. HSS, vol. V, no. 2, 2016. 103-115.

Brower, M. Developing Animals: Wildlife and Early American Photography. Minneapolis, London: University of Minnesota Press, 2011.

Bryan, A. „Alice's Struggle with Imperialism: Undermining the British Empire through Lewis Carroll's Alice's Adventures in Wonderland." The Final Chapters: Concluding Papers of the Journal of Children's Literature Studies. Wizard's Tower Books, 2012. 22-33.

Bull, S. (ed.). A Companion to Photography. Oxford: Wiley Blackwell, 2020.

Camuri, G., Fossati A. and Mathpal, Y. (eds.). Deer in Rock Art of India and Europe. New Delhi: Indira Gandhi National Centre for the Arts, 1993.

Clarke, G. The Photograph. Oxford, New York: Oxford University Press; Oxford History of Art, 1990.

Conn, P. Literature in America: An Illustrated History. Cambridge: Cambridge University Press, 1989.

Coveney, P. The Image of Childhood: The Individual and Society. London: Penguin Books, 1967.

Cunnigham, D., Fisher, A. and Mays, S. (eds.). Photography and Literature in the Twentieth Century. Cambridge: Cambridge Scholars Publishing, 2009.

Davenport, A. The History of Photography: An Overview. Albuquerque, New Mexico: University of New Mexico Press, 1999.

Davis, L. (ed.). Virginal Sexuality and Textuality in Victorian Literature. New York: State University of New York, 1993.

Dikinson, E. Poezija. Sarajevo: Svjetlost, 1988.

Flegel, M. Conceptualizing Cruelty to Children in Nineteenth-Century England: Literature, Representation, and the NSPCC. London and New York: Routledge, 2016.

Fuko, M. Istorija seksualnosti: volja za znanjem. Beograd: Prosveta, 1982.

Fulton, R. D. and Hoffenberg, P. H. (eds.). Oceania and the Victorian Imagination: Where All Things Are Possible. London and New York: Routledge, 2016.

Garcia, E. C. Photography as Fiction. Los Angeles: Getty Publications, 2010.

Hannavy, J. (ed.). Encyclopedia of Nineteenth-Century Photography, Volume 1, A-I. New York and London: Routledge, 2008.

Hirsch, R. Seizing the Light: A Social \& Aesthetic History of Photography. New York and London: Routledge, 2017.

Humm, M. "Memory and Photography: The Photo Albums of Virginia Woolf“, In: Cunnigham, D., Fisher, A. and Mays, S. (eds.). Photography and Literature in the Twentieth Century. Cambridge: Cambridge Scholars Publishing, 2009. 42-52.

Klein, B. „'The natural home of Englishmen': Froude's Oceana and the Writing of the Sea", In: Burden, R. and Kohl, S. (eds.). Landscape and Englishness. Amsterdam - New York, NY: Rodopi B. V., 2006. 103-123. 
Levine, G. The Realistic Imagination: English Fiction from Frankenstein to Lady Chatterly. Chicago: University of Chicago Press, 1983.

Manfredi, C. „Pacific Phantasmagorias: Robert Louis Stevenson's Pacific Photography“, In: Fulton, R. D. and Hoffenberg, P. H. (eds.). Oceania and the Victorian Imagination: Where All Things Are Possible. London and New York: Routledge, 2016. 11-31.

Mavor, C. Pleasures Taken: Performances of Sexuality and Loss in Victorian Photographs. Durham, North Carolina: Duke University Press, 1995.

Miller, D. Animals and Animal Symbols in World Culture. London: Cavendish Square Publishing, 2014.

Morse, D. D. and Danahay, M. A. Victorian Animal Dreams: Representations of Animals in Victorian Literature and Culture. Farnham: Ashgate, 2007.

Morse, D. D. ,'The Mark of the Beast': Animals as Sites of Imperial Encounter from Wuthering Heights to Green Mansions, In: Morse, D. D. and Danahay, M. A. Victorian Animal Dreams: Representations of Animals in Victorian Literature and Culture. Farnham: Ashgate, 2007. 181-201.

Munforte, P. „The Body of Ambivalence: The 'Alive, Yet Dead' Portrait in the Nineteenth Century“. Colchester: School of Philosophy and Art History at the University of Essex, 2015.

Newhall, B. The History of Photography: 1839 to the Present. New York: Museum of Modern Art, 1982.

Otten, T. After Innocence: Visions of the Fall in Modern Literature. Pittsburgh: University of Pittsburgh Press, 1982.

Rose, B., Gustavson, T. and Yano, H. „The History of the Twentieth Century Camera", In: Peres, M. R. (ed.). Focal Encyclopedia of Photography: Digital Imaging, Theory and Applications, History, and Science. Waltham, Massachusetts: Focal Press, 2007. 771-778.

Sattaur, J. Perceptions of Childhood in the Victorian Fin-de-siècle. Cambridge: Cambridge Scholars Publishing, 2011.

Seiberling, G. and Bloore, C. Amateurs, Photography, and the Mid-Victorian Imagination. Chicago and London: The University of Chicago Press, 1986.

Sontag, S. O fotografiji. Beograd: Kulturni centar Beograda, 2009.

Sontag, S. Regarding the Pain of Others. New York: Picador, 2003.

Sulaž, F. Estetika fotografije. Beograd: Kulturni centar Beograda, 2008.

Susina, J. The Place of Lewis Carroll in Children's Literature. London: Routledge, 2013.

Tennyson, A. L. Poems of Alfred Lord Tennyson. London: Collins Classics, 1968.

Tugendhat, E. O smrti. Beograd: Karpos, 2010.

Warren, L. (ed.). Encyclopedia of Twentieth-century Photography, Volume 2. London and New York: Routledge, 2006.

Weiner, N. and Kurpius, S. E. R. Shattered Innocence: A Practical Guide for Counseling Women Survivors of Childhood Sexual Abuse. Washington, DC: Taylor \& Francis, 1995. 
Goran T. Gavrić

\section{Literature and Photographs of Roger Fenton in the Context of Victorianism}

\section{Summary}

In this paper, we bring together Victorian literature, primarily Alice in Wonderland by Lewis Carroll and the poem about a wounded deer by Emily Dickinson, and Roger Fenton's photographs from the Crimean War and his photographs of deer. Thereby, a parallel is drawn between the powerful symbolism of the deer and its transformation in Victorian literature on the one hand, and the depiction of a wounded soldier in Fenton's photographs. By comparing scenes from war photographs, deer photographs, and the photograph of a wounded soldier, with scenes described in Victorian literature, we try to penetrate deeper into the photograph itself, using the richness of the literary language. We also discover that which photography and its visual language make very clear to us, which literature has either missed or needs too many words to achieve a similar effect. Considering that the relationship between literature and photography, in the context of the so-called photo-literature, is extremely complex, we try to shed some light on it using a modest sample of segments drawn from a few works of literature, and photographs by Roger Fenton.

Keywords: Victorian literature, Alice in Wonderland, poem about a wounded deer, Roger Fenton's photographs, photo-literature, deer-man transformation, wounded soldier, dead soldier

Примљено: 23. 4. 2020.

Прихваћено: 15. 11. 2020. 